\title{
Leptin stimulates ovarian cancer cell growth and inhibits apoptosis by increasing cyclin D1 and Mcl-1 expression via the activation of the MEK/ERK1/2 and PI3K/Akt signaling pathways
}

\author{
CHIACHEN CHEN ${ }^{1,3}$, YUAN-CHING CHANG ${ }^{2}$, MICHAEL S. LAN ${ }^{3,4}$ and MARY BRESLIN ${ }^{3,4}$
}

${ }^{1}$ Department of Veterinary Medicine, School of Veterinary Medicine, National Taiwan University; ${ }^{2}$ Department of Surgery, Mackay Memorial Hospital, Taipei, Taiwan, R.O.C.; ${ }^{3}$ Research Institute for Children, Children's Hospital; ${ }^{4}$ Departments of Pediatrics, and Biochemistry and Molecular Biology, Louisiana State University Health Sciences Center, New Orleans, LA, USA

Received October 1, 2012; Accepted November 13, 2012

DOI: 10.3892/ijo.2013.1789

\begin{abstract}
Obesity is known to be an important risk factor for many types of cancer, such as breast, prostate, liver and endometrial cancer. Recently, epidemiological studies have indicated that obesity correlates with an increased risk of developing ovarian cancer, the most lethal gynecological cancer in developed countries. Leptin is predominantly produced by adipocytes and acts as a growth factor and serum leptin levels positively correlate with the amount of body fat. In this study, we investigated the effects of leptin on the growth of ovarian cancer cells and the underlying mechanism(s) of action. Our results showed that leptin stimulated the growth of the OVCAR-3 ovarian cancer cell line using MTT assay and trypan blue exclusion. Using western blot analysis, we found that leptin enhanced the expression of cyclin D1 and Mcl-1, which are important regulators of cell proliferation and the inhibition of apoptosis. To investigate the signaling pathways that mediate the effects of leptin, cells were treated with leptin plus specific inhibitors of JAK2, PI3K/Akt and MEK/ERK1/2 and analysis of the phosphorylation state of proteins was carried out by western blot assays. We showed that the activation of the MEK/ERK1/2 and PI3K/Akt signaling pathways were involved in the growth-stimulating effect of leptin on ovarian cancer cell growth and the specific inhibitors of PI3K/Akt and MEK/ERK1/2 revealed that these two pathways interacted with each other. Our data demonstrate that leptin upregulates the expression of cyclin D1 and Mcl-1 to stimulate cell growth by activating the PI3K/Akt and MEK/ERK1/2 pathways in ovarian cancer.
\end{abstract}

Correspondence to: Mary B. Breslin, Research Institute for Children, Children's Hospital, Research and Education Building, 200 Henry Clay Ave., New Orleans, LA 70118, USA

E-mail: mbreslin@chnola-research.org

Key words: leptin, ovarian cancer, cell growth, anti-apoptotic effect, JAK2-MEK/ERK1/2 pathway, PI3K/Akt pathway

\section{Introduction}

Ovarian cancer is one of the most common gynecological cancers worldwide and the majority of patients are diagnosed with late-stage disease. The five-year survival rates of ovarian cancer are approximately $30 \%(1,2)$. Without effective screening methods, women who are diagnosed with ovarian cancer often present at an advanced stage associated with a poor survival rate (1). Thus, preventive strategies are required to reduce the mortality rate and provide early detection of the tumor. Few risk factors for ovarian cancer have been identified, such as age, family history of breast and ovarian cancer, and genetic mutations (3).

Obesity is a well-established risk factor for hormone-related cancers, such as breast, endometrial and prostate cancer (4). Recently, epidemiological studies have indicated that obesity is associated with an increased risk of ovarian cancer (5). Obese pre-menopausal women have a two-fold increased risk compared to individuals with a normal body mass index (BMI) (1). A high BMI strongly correlates with the occurrence of ovarian cancer $(5,6)$. The results of a meta-analysis showed that the risk of epithelial ovarian cancer among obese women was 30\% higher than women with a normal BMI. Overweight women have a $16 \%$ increased risk compared to those with a BMI within the healthy range (2). Obesity is not only positively associated with the incidence of ovarian cancer but is also related to a shorter time to recurrence and shorter overall survival. Obesity is a poor prognostic factor for ovarian cancer survival $(7,8)$. An increasing BMI is an independent negative predictor of disease-free and overall survival in ovarian cancer (9).

Adipose tissue serves not only as energy storage but also acts as endocrine tissue. Adiposity influences the synthesis of endogenous sex hormones, such as estrogen, progesterone and androgens. These sex hormones are believed to be involved in the etiology of ovarian cancer $(10,11)$. Apart from sex hormones, another major hormone produced by adipocytes that may mediate the correlation between obesity and ovarian cancer is leptin. Leptin, encoded by the obesity gene (OB) is a $16-\mathrm{kDa}$ adipokine. Leptin has been identified as a growth factor in certain hormone-related cancers, such as breast, prostate and endometrial cancer (12-15). Leptin exerts its activity through 
the membrane receptor, the obesity receptor (OB-R). The overexpression of $\mathrm{Ob}-\mathrm{R}$ has been observed in $59.2 \%$ of ovarian cancers and significantly correlates with poor progression-free survival (16). The growth factor-like functions of leptin have been observed in many types of cancer cells (16-19). However, the signaling pathways that directly underlie the leptin-stimulated ovarian cell growth and inhibition of apoptosis have not been extensively investigated.

Activated STAT3 had been shown to directly contribute to oncogenesis through the upregulation of genes encoding apoptosis inhibitors and cell-cycle regulators, such as Bcl-xL, Mcl-1 and cyclin D1/D2, resulting in increased cell proliferation and the prevention of apoptosis in a variety of human cancer cells (20). During cancer development and progression, anti-apoptotic proteins are usually overexpressed and result in the cancer cells becoming resistant to apoptosis (21). Mcl-1, a member of the Bcl-2 family, was first cloned from the human myeloblastic leukemia cell line, ML-1 (22). Mcl-1 acts as an anti-apoptotic factor in various tumors, such as human myeloid leukemia and hepatocellular carcinoma (23). Immunohistochemistry and semi-quantitative PCR analyses of Mcl-1 expression in ovarian cancer patients, have demonstrated that an increased Mcl-1 expression is associated with poor prognosis in ovarian cancer patients. High Mcl-1 expression has been shown to significantly correlate with advanced clinical stage, high histopathological grade and poor survival (24). Various growth factors and cytokines have been reported to induce $\mathrm{Mcl}-1$ expression, such as vascular endothelial growth factor (VEGF), interleukin (IL)-3 and IL-6 (25-27).

In the current study, we investigated whether leptin can stimulate ovarian cancer cell growth and prevent apoptosis under serum-starvation conditions. We first observed that leptin stimulated the expression of the anti-apoptotic protein, Mcl-1. Our data demonstrate that leptin enhances cell growth by activating the JAK2, MEK/ERK1/2 and PI3K/Akt pathways in ovarian cancer. Our results indicate that leptin plays an important role between obesity and the progression of ovarian cancer.

\section{Materials and methods}

Reagents and antibodies. Human recombinant leptin, tyrphostin AG490, U0126, PD98059, Ly294002 and wortmannin were purchased from Sigma Chemical Co. (St. Louis, MO). Antibodies were obtained and included monoclonal anti- $\beta$-actin antibody (Sigma Chemical Co.), polyclonal antibodies against phospho-Akt or phospho-ERK1/2 (Cell Signaling Technology, Beverly, MA), monoclonal antibody against Akt or cyclin D1 (BD Pharmingen, Palo Alto, CA), and polyclonal antibodies against ani-Mcl-1 or ERK1/2 (Santa Cruz Biotechnology, Inc., Santa Cruz, CA).

Cell culture. The OVCAR-3 human ovarian cancer cell line was obtained from the American Type Culture Collection. The cells were cultured in RPMI-1640 supplemented with $2 \mathrm{mM}$ glutamine (HyClone), $15 \mathrm{mM}$ HEPES (USB Corp.), $100 \mathrm{U} / \mathrm{L}$ penicillin $\mathrm{G}, 0.1 \mathrm{~g} / \mathrm{L}$ streptomycin, $25 \mathrm{mM}$ D-glucose, $1 \mathrm{mM}$ sodium pyruvate (Sigma) and $10 \%$ fetal bovine serum (Biological Industries, Ltd., Kibbutz Beit Haemek, Israel) in a $5 \% \mathrm{CO}_{2}$ incubator at $37^{\circ} \mathrm{C}$.
Cell number counting. Cells were seeded in 6-well plates, treated with the vehicle, recombinant human leptin, or AG490, U0126, PD98059, Ly294002 and wortmannin for the indicated periods of time, stained with $0.5 \%$ trypan blue (Biological Industries, Ltd.) and then counted.

MTT assay. The 3-(4,5-dimethylthiazolyl)-2,5-diphenyl tetrazolium bromide (MTT) proliferation assay was carried out according to a previous protocol (13). In brief, each cell treatment group was incubated in medium containing $2 \mathrm{mg} / \mathrm{ml}$ MTT reagent (Sigma Chemical Co.) at $37^{\circ} \mathrm{C}$ for $4 \mathrm{~h}$, the formazan crystals converted from tetrazolium salts by viable cells were dissolved in dimethyl sulfoxide (150 $\mu \mathrm{l} / \mathrm{well})$ and their absorbance at $570 \mathrm{~nm}$ was measured using a microplate spectrophotometer.

Western blot assay. Cells were extracted with lysis buffer (10 mM Tris- $\mathrm{HCl} \mathrm{pH} 7.5,150 \mathrm{mM} \mathrm{NaCl}, 10 \%$ glycerol, $1 \%$ Triton X-100, 1 mM DTT, $0.2 \mathrm{mM} \mathrm{PMSF}, 1 \mu \mathrm{g} / \mathrm{ml}$ aprotinin, $1 \mu \mathrm{g} / \mathrm{ml}$ leupeptin, $1 \mathrm{mM} \mathrm{Na}_{3} \mathrm{VO}_{4}$ and $1 \mathrm{mM} \mathrm{NaF}$ ) and separated on $8-15 \%$ SDS-PAGE gel. The proteins were electrotransferred onto a nitrocellulose membrane (Perkin-Elmer Life Sciences, Boston, MA). The membrane was blocked with $5 \%$ skim milk in TBST (20 mM Tris- $\mathrm{HCl} \mathrm{pH} 7.6,137 \mathrm{mM} \mathrm{NaCl}$ and $0.1 \%$ Tween-20), probed with the appropriate primary antibodies at $4^{\circ} \mathrm{C}$ overnight and incubated with HRP-conjugated secondary antibodies (Jackson Immuno Research Laboratories Inc., West Grove, PA) at room temperature for $1 \mathrm{~h}$. The blots were incubated with a chemiluminescence substrate (Amersham Biosciences, Little Chalfont, UK) and exposed to X-ray film (Fuji Photo Film Co., Tokyo, Japan).

Statistical analysis. Statistical analyses were calculated using a two-sided Student's t-test. All data are presented as the means \pm SD and the statistical differences are shown in the figure legends.

\section{Results}

Leptin stimulates ovarian cancer cell growth. Leptin exerts its functional effects through binding to the leptin receptors, $\mathrm{OB}-\mathrm{Rb}$ and OB-Ra expressed in ovarian cancer cells (19). In the present study, we examined the effect of leptin on ovarian cancer cell growth using trypan blue exclusion staining and MTT assay. OVCAR-3 cells were serum-deprived for $48 \mathrm{~h}$ and then treated with various concentrations of leptin for $48 \mathrm{~h}$. MTT assay showed that leptin stimulated OVCAR-3 cell growth in a dose-dependent manner. The stimulation was observed at a dose as low as $50 \mathrm{ng} / \mathrm{ml}$ (Fig. 1B). Using the trypan blue exclusion assay to estimate the amount of viable cells, the results showed that leptin enhanced cell growth not only in a dose-dependent but also in a time-dependent manner (Fig. 1A).

Leptin inhibits serum starvation-induced apoptosis. In addition to the stimulation of cancer cell growth, leptin treatment inhibited apoptosis either induced by sodium butyrate in colon cancer cells or by TGF $\beta$-1 in hepatocellular carcinoma cells $(18,28)$. Therefore, we further examined whether leptin exerts anti-apoptotic effects on OVCAR-3 cells. We measured the level of cleaved poly(ADP-ribose) polymerase 
A

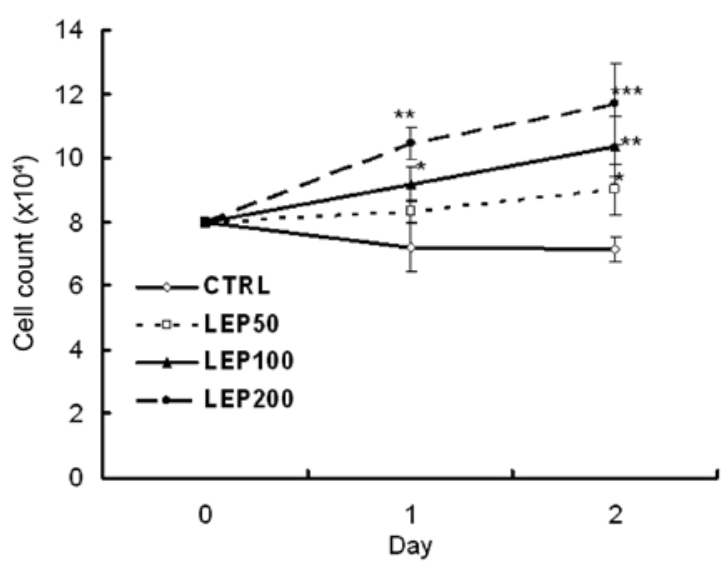

B

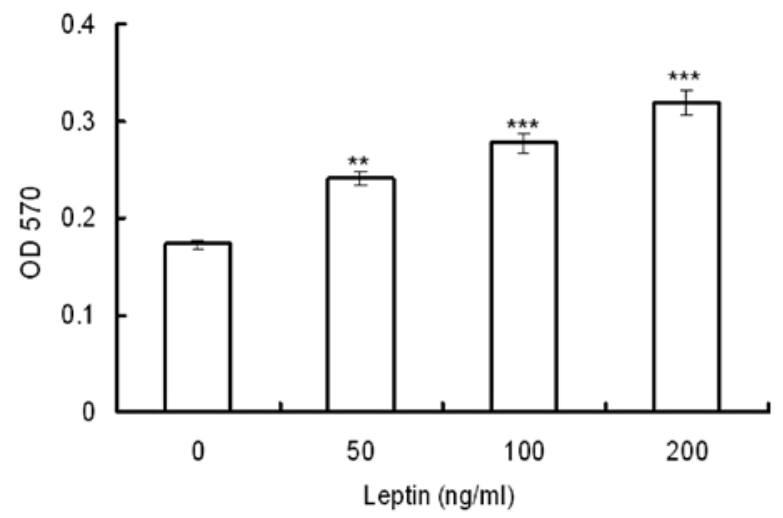

Figure 1. Leptin stimulates ovarian cancer cell growth. OVCAR-3 cells were seeded in 6- or 96-well plates and serum-deprived for $48 \mathrm{~h}$. The serum-starved cells were incubated with serial doses of leptin as indicated for an additional $48 \mathrm{~h}$. Cell viability was analyzed by (A) trypan blue exclusion staining and (B) MTT assays. LEP, leptin; CTRL, control; OD, optical density. " $\mathrm{P}<0.05$, ${ }^{* *} \mathrm{P}<0.01$ and ${ }^{* * *} \mathrm{P}<0.001$.

(PARP) using a western blot assay. In apoptotic mammalian cells, PARP, known as a death substrate, is degraded to an 89-kDa signature fragment. PARP cleavage by caspase-3 is a well-characterized event in the apoptotic pathway in mammalian cells. PARP is cleaved by caspase-3 early during apoptosis in many different cell lines $(29,30)$. Our results showed that the $116-\mathrm{kDa}$ active form of PARP was readily cleaved into 89- and 28-kDa fragments during serum-deprivation, showing that serum deprivation induces apoptosis in OVCAR-3 cells. The addition of leptin into the serum-free medium for $0,6,18$, 21, 26 and $48 \mathrm{~h}$ during serum starvation blocked the cleavage of PARP (Fig. 2). These results suggest that leptin exerts an anti-apoptotic effect on ovarian cancer cells.

Leptin stimulates the expression of cyclin DI and Mcl-1. Cyclin D1 is a growth sensor induced by a variety of growth factors and mitogens to trigger cell cycle progression (31). Therefore, we used western blot analysis to measure the expression of cyclin D1 in OVCAR-3 cells. At a low concentration $(50 \mathrm{ng} / \mathrm{ml})$, leptin increased the expression of cyclin D1 and the effect of leptin on cyclin D1 expression reached a maximum at the concentration of $200 \mathrm{ng} / \mathrm{ml}$ (Fig. 3). Since leptin exerts anti-apoptotic effects on OVCAR-3 cells, we sought to determine the mechanisms responsible for this response. Usually,

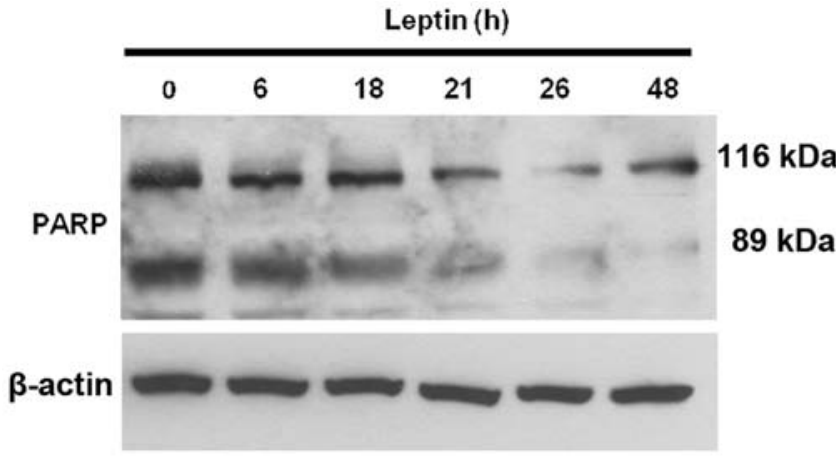

Figure 2. Leptin protects OVCAR-3 cells from serum deprivation-induced apoptosis. OVCAR-3 cells were serum-deprived for $48 \mathrm{~h}$ and then cultured in medium containing $200 \mathrm{ng} / \mathrm{ml}$ leptin for $0,6,18,21,26$ and $48 \mathrm{~h}$. The level of cleaved PARP was measured by western blot analysis using $\beta$-actin as the internal control for total protein. Similar results were observed from three independent experiments.

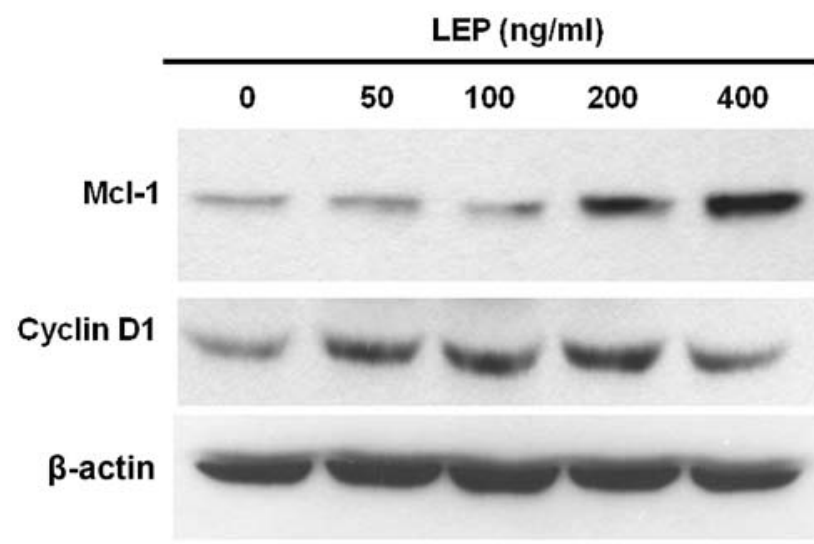

Figure 3. Leptin regulates the expression of cyclin D1 and the anti-apoptotic protein, Mcl-1. OVCAR-3 cells were serum-deprived for $48 \mathrm{~h}$ and then cultured in serum-free medium containing the indicated concentration of leptin for $24 \mathrm{~h}$. The levels of cyclin D1 and Mcl-1 protein were measured using western blot analysis. The blots were stripped and reprobed using a $\beta$-actin antibody as the internal control for equal loading of total protein. Similar results were observed from three independent experiments. LEP, leptin.

the overexpression of Mcl-1 delays apoptosis induced by growth factor withdrawal (32). Increased Mcl-1 expression has been associated with poor prognosis in ovarian cancer (24). OVCAR-3 cells treated with leptin showed a dose-dependent increase in the amount of Mcl-1 protein. The effect was maximal at $400 \mathrm{ng} / \mathrm{ml}$ leptin treatment (Fig. 3). As shown in Fig. 4A, leptin acutely stimulated Mcl-1 expression within 5-60 min; this effect diminished after $2 \mathrm{~h}$ of treatment. A second peak in leptin-induced Mcl-1 expression was detected at $24 \mathrm{~h}$ (Fig. 4B).

Activation of JAK2, PI3K/Akt and MEK/ERK1/2 pathways mediate leptin-stimulated cell growth of OVCAR-3 cells. In order to determine the intracellular signaling pathways responsible for the effect observed with leptin treatment, we analyzed the phosphorylation status of JAK2, Akt and ERK1/2. The phosphorylated forms of JAK2, Akt and ERK1/2 were dose-dependently increased by leptin in the OVCAR-3 cells (Fig. 5B). Simultaneously, the time-course experiments showed 
A

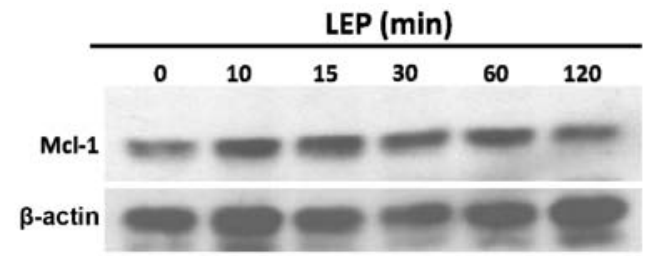

B

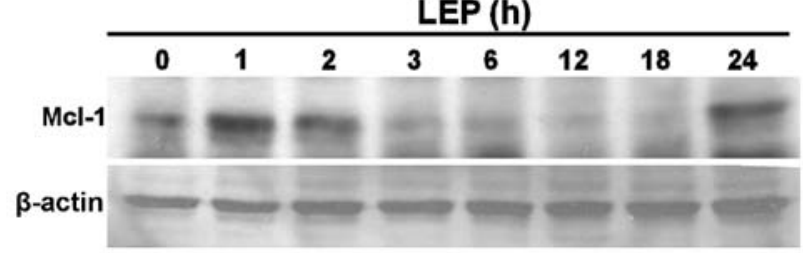

Figure 4. Leptin induced Mcl-1 expression in two phases in OVCAR-3 cells. OVCAR-3 cells were serum-deprived for $48 \mathrm{~h}$ and cultured in serum-free medium containing $200 \mathrm{ng} / \mathrm{ml}$ leptin for the indicated periods of time. Mcl-1 protein levels were measured using western blot analysis. The membranes were stripped and reprobed using a $\beta$-actin antibody as the internal control to normalize the amount of protein loaded per lane. Similar results were observed from three separate experiments. LEP, leptin.

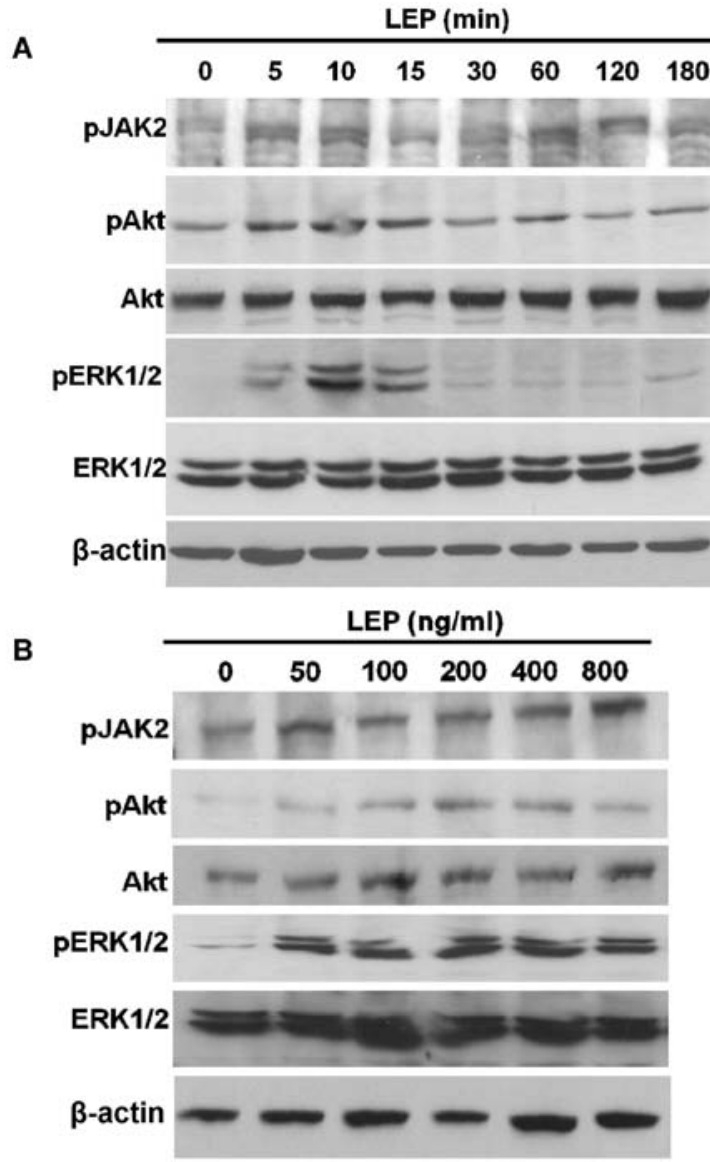

Figure 5. Leptin induces the phophorylation of JAK2, Akt and ERK1/2 in OVCAR-3 cells. (A) Similar western blot analysis was carried out with the cell lysates of the OVCAR-3 cells treated with $200 \mathrm{ng} / \mathrm{ml}$ leptin for the indicated times. Data represent three independent experiments. The blots were stripped and reprobed with $\beta$-actin antibody to serve as the protein loading control. (B) After 48-h serum deprivation, leptin was added to the serum-free medium of OVCAR-3 cells for $5 \mathrm{~min}$ with increasing concentrations as indicated, and then the protein was collected. The amounts of the phosphorylated forms of JAK2 (p-JAK2), Akt (p-Akt), or ERK1/2 (p-ERK1/2) were detected using western blot analysis. The same blots were stripped and reprobed with antibodies specific for total proteins of Akt or ERK1/2. LEP, leptin.

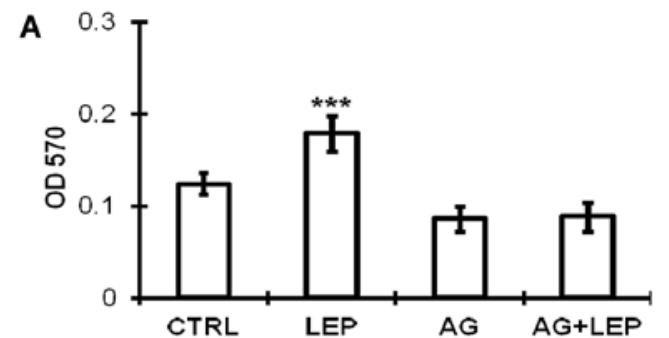

B
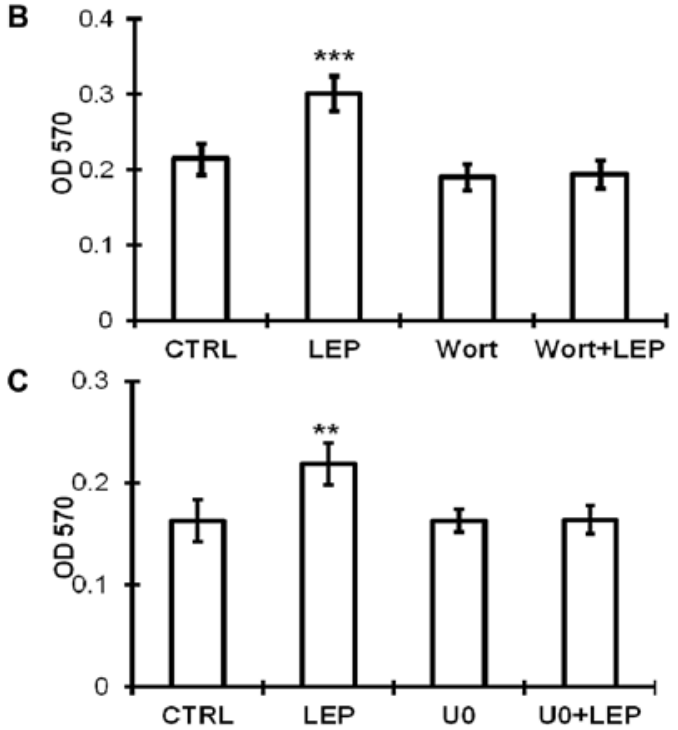

Figure 6. Pharmacological inhibitors of JAK2, PI3K/Akt and MEK/ERK1/2 prevent leptin-stimulated ovarian cancer cell growth. After 48-h serum deprivation, OVCAR-3 cells were treated with the vehicle (CTRL), $200 \mathrm{ng} / \mathrm{ml}$ leptin (LEP), (A) $40 \mu \mathrm{M}$ AG490 (AG) or $200 \mathrm{ng} / \mathrm{ml}$ leptin plus $40 \mu \mathrm{M}$ AG490 (LEP + AG), (B) $250 \mathrm{nM}$ wortmannin (Wort) or $200 \mathrm{ng} / \mathrm{ml}$ leptin plus $250 \mathrm{nM}$ wortmannin (LEP + Wort) and (C) $10 \mu \mathrm{M}$ U0126 (U0) or $200 \mathrm{ng} / \mathrm{ml}$ leptin plus $10 \mu \mathrm{M} \mathrm{U} 0126$ (LEP + U0) in serum-free medium for $48 \mathrm{~h}$ and then cell viability was measured by MTT assay. The means and standard deviations (SD) were calculated from 24 replicates. Statistically significant differences compared to the control group (CTRL) were noted as ${ }^{* *} \mathrm{P}<0.01$ and ${ }^{* * *} \mathrm{P}<0.001$. OD, optical density.

that the levels of the phosphorylated forms of JAK2, Akt and ERK1/2 were increased as early as $5 \mathrm{~min}$ in the OVCAR-3 cells during leptin treatment (Fig. 5A). Leptin treatment resulted in the activation of JAK2, Akt and ERK1/2 kinases in the ovarian cancer cells. Subsequently, we used pharmacological inhibitors to determine the involvement of these signaling kinases on the growth-stimulating effect of leptin. The leptin-stimulated growth of the OVCAR-3 cells was abolished by the inhibitor specific for JAK2 (AG490) (Fig. 6A), PI3K/Akt (wortmannin) (Fig. 6B) and MEK/ERK1/2 (U0126) (Fig. 6C), which is consistent with the activation of the JAK2, PI3K/Akt and MEK/ERK1/2 pathways.

Leptin stimulates the expression of cyclin D1 and Mcl-1 through the activation of JAK2-associated signaling pathways. To elucidate the mechanisms by which JAK2, PI3K/ Akt and MEK/ERK1/2 mediate leptin-induced cyclin D1 and Mcl-1 expression, we examined the effects of their inhibitors on cyclin D1 and Mcl-1 expression. The specific inhibitors for JAK2 (AG490), PI3K/Akt (Ly294002), or MEK/ERK1/2 (U0126), blocked the leptin induction of cyclin D1 and Mcl-1 protein expression (Fig. 7A and B). Taken together, these data 
A

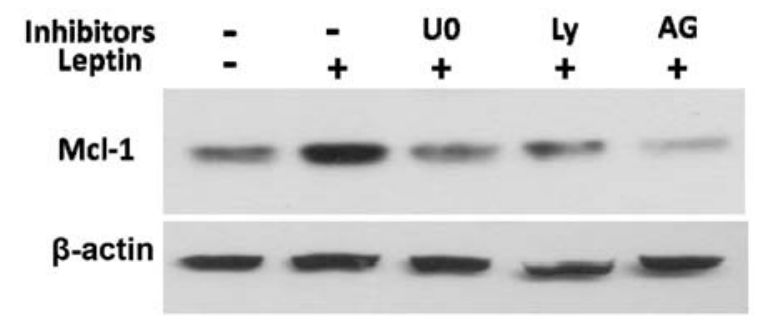

B

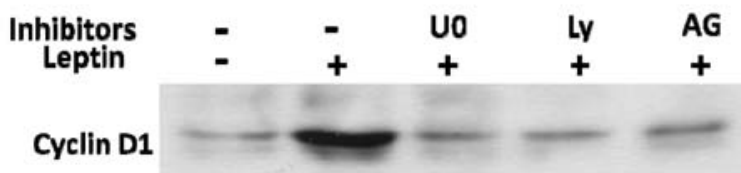

$\beta$-actin

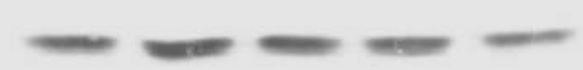

Figure 7. Pharmacological inhibitors of JAK2, PI3K/Akt and MEK/ERK1/2 prevent leptin-induced cyclin D1 and Mcl-1 expression. OVCAR-3 cells were serum-starved for $48 \mathrm{~h}$ and then treated with the vehicle (-), $200 \mathrm{ng} / \mathrm{ml} \mathrm{leptin}(+)$, $200 \mathrm{ng} / \mathrm{ml}$ leptin without (-) or with (+), $40 \mu \mathrm{M}$ AG490 (AG), $10 \mu \mathrm{M}$ U0126 (U0), or $50 \mathrm{mM} \mathrm{Ly} 294002$ (Ly) for $24 \mathrm{~h}$. After 24-h treatment, the cell extracts were harvested and subjected to western blot analysis to detect (A) cyclin D1 and (B) Mcl-1 protein. The blots were reprobed with a $\beta$-actin antibody to normalize the protein loading. Data represent three independent experiments.

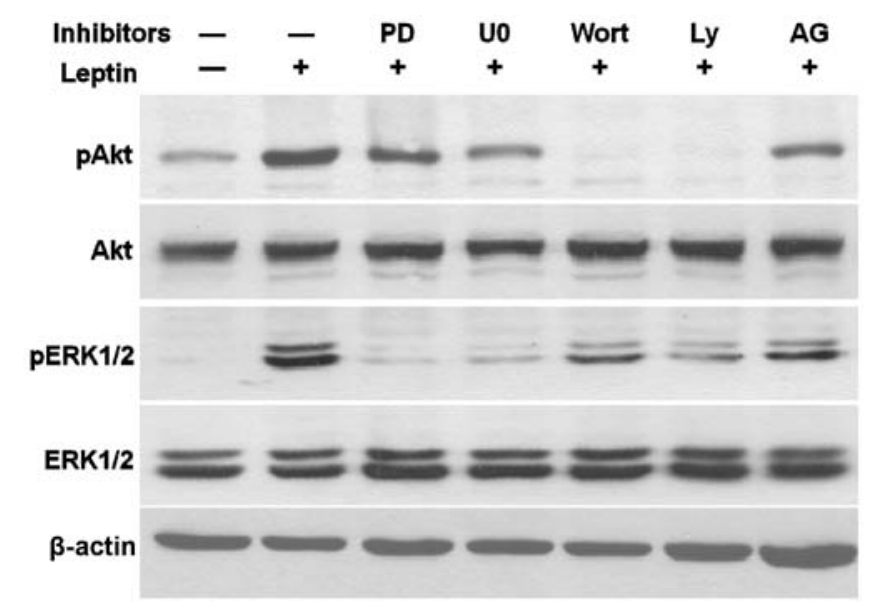

Figure 8. Leptin triggers JAK2-MEK/ERK1/2 and PI3K/Akt signaling pathways. After 48-h serum deprivation and 30-min pre-treatment with the vehicle (-), $40 \mu \mathrm{M}$ AG490 (AG), $50 \mathrm{mM}$ Ly294002 (Ly), $250 \mathrm{nM}$ wortmannin (Wort), $20 \mu \mathrm{M}$ PD98059 or $10 \mu \mathrm{M}$ U0126, OVCAR-3 cells were treated with vehicle (-) or $200 \mathrm{ng} / \mathrm{ml}$ leptin (+) in serum-free medium for $10 \mathrm{~min}$. The level of the phosphorylated forms of Akt (pAkt) or ERK1/2 (pERK1/2) was detected with western blot analysis. The same blots were stripped and reprobed with antibodies specific for total protein of Akt or ERK1/2. $\beta$-actin was used as the internal control. Data represent three independent experiments.

reveal that leptin activates the signaling pathways, including JAK2, PI3K/Akt and MEK/ERK1/2 to enhance the expression of cyclin D1 and the anti-apoptotic protein, Mcl-1, which subsequently stimulates OVCAR-3 cell growth and prevents apoptosis.

Leptin activates crosstalk among JAK2, PI3K/Akt and MEK/ERK1/2 signaling pathways. Using AG490, the inhibitor of JAK2, PD98059 and U0126, the inhibitors of MEK/ERK1/2 and the inhibitors of PI3K/Akt, wortmannin and Ly294002, we examined the leptin-stimulated phosphorylation of Akt and ERK $1 / 2$ to elucidate the crosstalk among these signaling pathways in OVCAR-3 cells (Fig. 8). As expected, U0126 and PD98059 specifically blocked the leptin-induced phosphorylation of ERK1/2, while wortmannin and Ly294002 inhibited the leptin-induced phosphorylation of Akt. The specific blocker of JAK2, AG490, decreased leptin-phosphorylated ERK1/2 and Akt. Wortmannin and Ly294002, not only inhibited leptin-activated Akt but also completely abrogated the effects of leptin on ERK1/2 phosphorylation. Similar results were observed with U0126 and PD98059 treatments. The inhibitors of the MEK/ERK1/2 pathway concomitantly blocked the leptin-activated phosphorylation of ERK1/2 and partially decreased the level of leptin-induced phosphorylated Akt. According to these findings, we propose that leptin triggers a JAK2-initiated signaling cascade, comprised of the PI3K/Akt and MEK/ERK1/2 pathways in ovarian cancer.

\section{Discussion}

Obesity is a significant health concern in developed countries with a dramatically increased incidence over the last decade. In the US, more than one third of the adults (35.7\%) are obese and $68.8 \%$ are considered overweight based on their BMI $(33,34)$. Obesity has been identified as a risk factor in diabetes, cardiovascular diseases and in many types of cancer, such as breast, esophageal, prostate, colon and liver cancer (35). The adipokine, leptin, may be an important factor in the growth of ovarian cancer (16). In epidemiological surveys, obesity has been shown to increase ovarian cancer incidence, and shorten the time of survival and recurrence $(5,9)$. However, the molecular mechanisms underlying the clinical observations remain unclear. In the present study, we investigated the effects of leptin on ovarian cancer cells. Our results show that leptin stimulates ovarian cancer cell growth and exerts an anti-apoptotic effect by increasing the expression of cyclin D1 and Mcl-1 proteins.

Apart from the effect of leptin on cell growth and the inhibition of apoptosis, our results showed that leptin induced cyclin D1 expression, which plays a crucial role in cell proliferation in a variety of cancer cells, such as breast cancer, hepatocellular carcinoma and ovarian cancer cells. In addition, to our knowledge, we are the first to show that leptin directly stimulates Mcl-1 expression. Mcl-1 is a member of the $\mathrm{Bcl}-2$ family. The expression of the $\mathrm{Bcl}-2$ family members is frequently deregulated during carcinogenesis. Mcl-1 is frequently amplified in human cancers (23). The downregulation of Mcl-1 is essential to induce cell death in ovarian cancer cells in response to $\mathrm{Bcl}-2$ inhibitors. siRNA treatment to inhibit Mcl-1 expression has been shown to induce apoptosis in ovarian cancer cells (36-38). In our study, leptin acutely induced Mcl-1 expression within 10-60 min; this effect that rapidly diminished within $3 \mathrm{~h}$ (Fig. 4). The half-life of Mcl-1 is around $1 \mathrm{~h}$ compared to $10-14 \mathrm{~h}$ for Bcl-2 (39). Mcl-1 mRNA expression evolves and changes rapidly and this feature perhaps explains why Mcl-1 expression may be rapidly increased or downregulated with cytokines and differentiation factors. Mcl-1 thus differs from other members of the Bcl-2 family in acting as an immediate response molecule to protect cells 
against apoptosis (23). In our experiments, leptin stimulated Mcl-1 expression in two phases. Apart from acute stimulation, we found that leptin induced Mcl-1 expression at $24 \mathrm{~h}$ to the same levels observed within $60 \mathrm{~min}$.

The phosphorylation of JAK2 is thought to be the first event following the binding of leptin to its cellular receptor. Subsequently, activated JAK2 triggers other signaling pathways. In our study, AG490, an inhibitor of JAK2, abolished the leptin-induced activation of the downstream pathways, PI3K/Akt and MEK/ERK1/2. Previous studies have suggested that the response to leptin treatment is transmitted via the MAP kinase and PI3K/Akt pathways in ovarian cancer cells $(16,19)$. Using specific inhibitors of the MEK/ERK1/2 and PI3K/Akt pathways, we observed that both pathways interacted with each other. Both pathways are required to mediate leptin-stimulated cell growth and inhibition of apoptosis.

In the present study, we demonstrate that leptin stimulates cyclin D1 and Mcl-1 protein expression. Furthermore, leptin induces cell proliferation and inhibits apoptosis in ovarian cancer cells. Our results also identify the signaling pathways responsible for ovarian cancer cell growth and inhibition of apoptosis in response to leptin, providing a direct association between obesity and ovarian carcinogenesis.

\section{Acknowledgements}

We thank Dr Ing-Cherng Guo (deceased, March 2, 2008) for his major contribution in providing us with the initial experimental design and support. This study was supported by the Research Institute for Children at the Children's Hospital, New Orleans, LA, USA.

\section{References}

1. Beehler GP, Sekhon M, Baker JA, Teter BE, McCann SE, Rodabaugh KJ and Moysich KB: Risk of ovarian cancer associated with BMI varies by menopausal status. J Nutr 136: 2881-2886, 2006.

2. Olsen CM, Green AC, Whiteman DC, Sadeghi S, Kolahdooz F and Webb PM: Obesity and the risk of epithelial ovarian cancer: a systematic review and meta-analysis. Eur J Cancer 43: 690-709, 2007.

3. Ioka A, Tsukuma H, Ajiki W and Oshima A: Ovarian cancer incidence and survival by histologic type in Osaka, Japan. Cancer Sci 94: 292-296, 2003.

4. Bray GA: The underlying basis for obesity: relationship to cancer. J Nutr 132: 3451S-3455S, 2002.

5. Leitzmann MF, Koebnick C, Danforth KN, Brinton LA Moore SC, Hollenbeck AR, Schatzkin A and Lacey JV Jr: Body mass index and risk of ovarian cancer. Cancer 115: 812-822, 2009.

6. Schouten LJ, Rivera C, Hunter DJ, Spiegelman D, Adami HO, Arslan A, Beeson WL, van den Brandt PA, Buring JE, Folsom AR, Fraser GE, Freudenheim JL, Goldbohm RA, Hankinson SE, Lacey JV Jr, Leitzmann M, Lukanova A, Marshall JR, Miller AB Patel AV, Rodriguez C, Rohan TE, Ross JA, Wolk A, Zhang SM and Smith-Warner SA: Height, body mass index, and ovarian cancer: a pooled analysis of 12 cohort studies. Cancer Epidemiol Biomarkers Prev 17: 902-912, 2008.

7. Calle EE, Rodriguez C, Walker-Thurmond $\mathrm{K}$ and Thun MJ: Overweight, obesity, and mortality from cancer in a prospectively studied cohort of U.S. adults. N Engl J Med 348: 1625-1638, 2003.

8. Rodriguez C, Jacobs EJ, Patel AV, Calle EE, Feigelson HS, Fakhrabadi-Shokoohi D and Thun MJ: Jewish ethnicity and prostate cancer mortality in two large US cohorts. Cancer Causes Control 13: 271-277, 2002.
9. Pavelka JC, Brown RS, Karlan BY, Cass I, Leuchter RS, Lagasse LD and Li AJ: Effect of obesity on survival in epithelial ovarian cancer. Cancer 107: 1520-1524, 2006.

10. Key T, Appleby P, Barnes I, Reeves G; Endogenous Hormones and Breast Cancer Collaborative Group: Endogenous sex hormones and breast cancer in postmenopausal women: reanalysis of nine prospective studies. J Natl Cancer Inst 94: 606-616, 2002.

11. Risch HA: Hormonal etiology of epithelial ovarian cancer, with a hypothesis concerning the role of androgens and progesterone. J Natl Cancer Inst 90: 1774-1786, 1998.

12. Hu X, Juneja SC, Maihle NJ and Cleary MP: Leptin - a growth factor in normal and malignant breast cells and for normal mammary gland development. J Natl Cancer Inst 94: 1704-1711, 2002.

13. Chen C, Chang YC, Liu CL, Chang KJ and Guo IC: Leptin-induced growth of human ZR-75-1 breast cancer cells is associated with up-regulation of cyclin D1 and c-Myc and down-regulation of tumor suppressor p53 and p21WAF1/CIP1. Breast Cancer Res Treat 98: 121-132, 2006.

14. Sharma D, Saxena NK, Vertino PM and Anania FA: Leptin promotes the proliferative response and invasiveness in human endometrial cancer cells by activating multiple signal-transduction pathways. Endocr Relat Cancer 13: 629-640, 2006.

15. Somasundar P, Frankenberry KA, Skinner H, Vedula G, McFadden DW, Riggs D, Jackson B, Vangilder R, Hileman SM and Vona-Davis LC: Prostate cancer cell proliferation is influenced by leptin. J Surg Res 118: 71-82, 2004.

16. Uddin S, Bu R, Ahmed M, Abubaker J, Al-Dayel F, Bavi P and Al-Kuraya KS: Overexpression of leptin receptor predicts an unfavorable outcome in Middle Eastern ovarian cancer. Mol Cancer 8: 74, 2009.

17. Garofalo C and Surmacz E: Leptin and cancer. J Cell Physiol 207: 12-22, 2006.

18. Chen C, Chang YC, Liu CL, Liu TP, Chang KJ and Guo IC: Leptin induces proliferation and anti-apoptosis in human hepatocarcinoma cells by up-regulating cyclin D1 and downregulating Bax via a Janus kinase 2-linked pathway. Endocr Relat Cancer 14: 513-529, 2007.

19. Choi JH, Park SH, Leung PC and Choi KC: Expression of leptin receptors and potential effects of leptin on the cell growth and activation of mitogen-activated protein kinases in ovarian cancer cells. J Clin Endocrinol Metab 90: 207-210, 2005.

20. Buettner R, Mora LB and Jove R: Activated STAT signaling in human tumors provides novel molecular targets for therapeutic intervention. Clin Cancer Res 8: 945-954, 2002.

21. Heiser D, Labi V, Erlacher M and Villunger A: The Bcl-2 protein family and its role in the development of neoplastic disease. Exp Gerontol 39: 1125-1135, 2004.

22. Reynolds JE, Yang T, Qian L, Jenkinson JD, Zhou P, Eastman A and Craig RW: Mcl-1, a member of the Bcl-2 family, delays apoptosis induced by c-Myc overexpression in Chinese hamster ovary cells. Cancer Res 54: 6348-6352, 1994.

23. Michels J, Johnson PW and Packham G: Mcl-1. Int J Biochem Cell Biol 37: 267-271, 2005.

24. Shigemasa K, Katoh O, Shiroyama Y, Mihara S, Mukai K, Nagai $\mathrm{N}$ and Ohama K: Increased MCL-1 expression is associated with poor prognosis in ovarian carcinomas. Jpn J Cancer Res 93: 542-550, 2002.

25. Kuo ML, Chuang SE, Lin MT and Yang SY: The involvement of PI 3-K/Akt-dependent up-regulation of Mcl-1 in the prevention of apoptosis of Hep3B cells by interleukin-6. Oncogene 20: 677-685, 2001.

26. Leu CM, Chang C and Hu C: Epidermal growth factor (EGF) suppresses staurosporine-induced apoptosis by inducing mcl-1 via the mitogen-activated protein kinase pathway. Oncogene 19: $1665-1675,2000$

27. Wei LH, Kuo ML, Chen CA, Chou CH, Cheng WF, Chang MC, Su JL and Hsieh CY: The anti-apoptotic role of interleukin-6 in human cervical cancer is mediated by up-regulation of Mcl-1 through a PI 3-K/Akt pathway. Oncogene 20: 5799-5809, 2001.

28. Rouet-Benzineb P, Aparicio T, Guilmeau S, Pouzet C, Descatoire V, Buyse M and Bado A: Leptin counteracts sodium butyrate-induced apoptosis in human colon cancer HT-29 cells via NF- $\kappa$ B signaling. J Biol Chem 279: 16495-16502, 2004.

29. Nicholson DW, Ali A, Thornberry NA, Vaillancourt JP, Ding CK, Gallant M, Gareau Y, Griffin PR, Labelle M, Lazebnik YA, et al: Identification and inhibition of the ICE/CED-3 protease necessary for mammalian apoptosis. Nature 376: 37-43, 1995. 
30. Germain M, Affar EB, D'Amours D, Dixit VM, Salvesen GS and Poirier GG: Cleavage of automodified poly(ADP-ribose) polymerase during apoptosis. Evidence for involvement of caspase-7. J Biol Chem 274: 28379-28384, 1999.

31. Knudsen KE, Diehl JA, Haiman CA and Knudsen ES: Cyclin D1: polymorphism, aberrant splicing and cancer risk. Oncogene 25: 1620-1628, 2006.

32. Wang JM, Chao JR, Chen W, Kuo ML, Yen JJ and Yang-Yen HF: The antiapoptotic gene mcl-1 is up-regulated by the phosphatidylinositol 3-kinase/Akt signaling pathway through a transcription factor complex containing CREB. Mol Cell Biol 19: 6195-6206, 1999.

33. Ogden CL, Carroll MD, Kit BK and Flegal KM: Prevalence of obesity in the United States, 2009-2010. NCHS Data Brief pp1-8, 2012.

34. Flegal KM, Carroll MD, Kit BK and Ogden CL: Prevalence of obesity and trends in the distribution of body mass index among US adults, 1999-2010. JAMA 307: 491-497, 2012.

35. Bray GA: Drug treatment of obesity. Rev Endocr Metab Disord 2: 403-418, 2001
36. Simonin K, Brotin E, Dufort S, Dutoit S, Goux D, N'Diaye M, Denoyelle C, Gauduchon P and Poulain L: Mcl-1 is an important determinant of the apoptotic response to the $\mathrm{BH} 3$-mimetic molecule HA14-1 in cisplatin-resistant ovarian carcinoma cells. Mol Cancer Ther 8: 3162-3170, 2009.

37. Varin E, Denoyelle C, Brotin E, Meryet-Figuière M, Giffard F, Abeilard E, Goux D, Gauduchon P, Icard P and Poulain L: Downregulation of Bcl-xL and Mcl-1 is sufficient to induce cell death in mesothelioma cells highly refractory to conventional chemotherapy. Carcinogenesis 31: 984-993, 2010.

38. Brotin E, Meryet-Figuière $M$, Simonin K, Duval RE, Villedieu M, Leroy-Dudal J, Saison-Behmoaras E, Gauduchon P, Denoyelle C and Poulain L: Bcl-XL and MCL-1 constitute pertinent targets in ovarian carcinoma and their concomitant inhibition is sufficient to induce apoptosis. Int J Cancer 126: 885-895, 2010.

39. Weng C, Li Y, Xu D, Shi Y and Tang H: Specific cleavage of Mcl-1 by caspase-3 in tumor necrosis factor-related apoptosis-inducing ligand (TRAIL)-induced apoptosis in Jurkat leukemia T cells. J Biol Chem 280: 10491-10500, 2005. 